Article

\title{
Political Reactionism as Affective Practice: UKIP Supporters and Non-Voters in Pre-Brexit England
}

\author{
Gavin Brent Sullivan ${ }^{1,2}$ \\ ${ }^{1}$ International Psychoanalytic University Berlin, Germany; E-Mail: gavin.sullivan@ipu-berlin.de \\ ${ }^{2}$ Centre for Trust, Peace and Social Relations, Coventry University, UK; E-Mail: ab7809@coventry.ac.uk
}

Submitted: 9 March 2021 | Accepted: 5 July 2021 | Published: 27 August 2021

\begin{abstract}
United Kingdom Independence Party (UKIP) supporters and non-voters in England participate respectively in forms of engaged and disengaged anti-political activity, but the role of individual, group-based, and collective emotions is still unclear. Drawing upon recent analyses of the complex emotional dynamics (e.g., ressentiment) underpinning the growth of right-wing populist political movements and support for parties such as UKIP, this analysis explores the affective features of reactionary political stances. The framework of affective practices is used to show how resentful affects are created, facilitated, and transformed in sharing or suppressing populist political views and practices; that is, populism is evident not only in the prevalence and influence of illiberal and anti-elite discourses but also should be explored as it is embodied and enacted in "past focused" and "change resistant" everyday actions and in relation to opportunities that "sediment" affect-laden political positions and identities. Reflexive thematic analysis of data from qualitative interviews with UKIP voters and non-voters (who both supported leaving the EU) in 2015 after the UK election but before the EU referendum vote showed that many participants: 1 ) shared "condensed" complaints about politics and enacted resentment towards politicians who did not listen to them, 2) oriented towards shameful and purportedly shameless racism about migrants, and 3) appeared to struggle with shame and humiliation attributed to the EU in a complex combination of transvaluation of the UK and freedom of movement, a nostalgic need for restoration of national pride, and endorsement of leaving the EU as a form of "change backwards."
\end{abstract}

\section{Keywords}

affective practice; Brexit; EU referendum; non-voters; populism; national pride; reactionism; ressentiment; shame; UKIP

\section{Issue}

This article is part of the issue "Reactionary Politics and Resentful Affect in Populist Times" edited by Tereza Capelos (University of Birmingham, UK), Stavroula Chrona (King's College London, UK), Mikko Salmela (University of Helsinki, Finland / University of Copenhagen, Denmark), and Cristiano Bee (Oxford Brookes University, UK).

(C) 2021 by the author; licensee Cogitatio (Lisbon, Portugal). This article is licensed under a Creative Commons Attribution 4.0 International License (CC BY).

\section{Introduction}

A widely accepted view of populism as a "thin ideology" (Mudde \& Kaltwasser, 2017) emphasises a central distinction between "the people" and "the elite" which does not map in a simple way onto established right and left ideologies or a common political programme (Taylor et al., 2020). In addition, there are significant national and cultural variations in patterns of "populist attitudes" measured at the individual level (Castanho Silva et al., 2020) and self-reported anti-establishment sentiment (Droste, 2021). Moreover, as Obradović et al. (2020) note, right-wing populist rhetoric is triggered bybut not solely the product of-one's economic standing in society and, specifically, a felt sense of deprivation relative to others (Jay et al., 2019; Mols \& Jetten, 2016; Salmela \& von Scheve, 2017, 2018). Regarding the $2016 \mathrm{EU}$ referendum in the UK, therefore, for the Leave campaign to succeed it needed to unite "both highincome and low-income earners through conceptualising the in-group as a moral majority" (Obradović et al., 2020, p. 126) against out-group political elites and immigrants. 
In debates about populism, a focus on a reactionary "complex political orientation" provides a new perspective on such populist political behaviour as supporting the United Kingdom Independence Party (UKIP) or voting for Brexit, because it highlights a critical motivational role for "resentful affectivity [combined] with the forceful desire to return to the past" (Capelos \& Katsanidou, 2018, p. 1272). Not to be confused with simple group-based nostalgia (Smeekes, 2019; Wohl et al., 2020), reactionism appeals to "an idealized past and social order and the desire for restoration of the past marks the broadly similar narratives of contemporary 'radical' populist, neo-Nazi, and ethno-nationalist political parties" such as the National Front in France (Capelos \& Katsanidou, 2018, p. 1284). UKIP was able to attract voters from both the left (e.g., traditional Labour supporters) and the right of UK politics to support a core bundle of anti-establishment, anti-immigration, and anti-EU messages (Hughes, 2019). Before the referendum, for example, the Leave campaign repeatedly used the message "Take back control" as part of a reactionary "depiction of a stalled present and a future that is compromised by the unstoppable changes imposed by elites on the country against its will" (Capelos \& Katsanidou, 2018, p. 1284).

This article addresses the contribution of reactionary orientations to understanding support for populist parties, movements, and views via recent accounts that focus not just on anger, fear, resentment, and their potential combinations with a lack of efficacy, but also on the complex emotional phenomenon of ressentiment. As exemplified by Salmela and Capelos (2021), the ressentiment driving reactionary political behaviour is not a complex combination of low levels of hope and low political efficacy with high levels of anxiety or anger (Capelos \& Demertzis, 2018), but rather an emotional mechanism with two parallel transvaluation processes. These processes transform "what was once desired or valued yet unattainable into something reassessed as undesirable and rotten, and one's own self from inferior, a loser, to being noble and superior" (Salmela \& Capelos, 2021, p. 191). The article also explores whether these phenomena can be found in England among non-voters and populist party supporters, groups that Kemmers et al. (2016) argue are exemplars of an "anti-establishment career" from "democracy's deviants" (Kemmers et al., 2016, p. 757) in their research conducted in the Netherlands.

In the following sections, the conceptualization of ressentiment as underpinning a reactionary orientation towards politically significant stances associated with populism is briefly reviewed, before the most recent account of ressentiment as an emotional mechanism is examined. A case is then made for understanding reactionary orientations not in terms of personality features or traits, and causal mechanisms, but instead within an affective practices framework (Wetherell, 2012). In this approach, patterns and flows of affectivity are examined using an alternative ontological focus on meaning, activity, and agency. The research questions are stated explicitly in the final introductory section.

\section{Emotion-Focused Explanations of Reactionary 'Anti-Preferences' and Populist Support}

Presenting an emotion-focused analysis of the EU referendum, Cromby (2019) has argued that explanations of Brexit have largely been framed in terms of the "feeling-organising myth" in which Brexit represents the anger and apathy of those left behind in Britain by market forces and globalisation (McKenzie, 2017a, 2017b). On this account, feelings of "anger, resentment, discontent, and hope, of feeling left behind or left out" (Cromby, 2019 , p. 59) reflected the reality of growing inequality in the UK and contributed to a concomitant irrational diversion of "feelings of resentment from powerful elites" (Cromby, 2019, p. 59) towards immigrants. Cromby's analysis is broadly consistent with other explanations which favour a reactionist-like account of the demand-side of populism or backlash politics (Busher et al., 2018) and feature a complex blend of individual and group-based anger, fear, hope, loss, nostalgia, and pride. Capelos and Demertzis (2018), for example, argue that ressentimentful affectivity is characterised by low levels of hope and efficacy, but high levels of anxiety or anger; and that this specific cluster of affectivity is a "compensatory emotion of the powerless that expedites transvalution so that the person can stand and handle his or her frustrations" (Capelos \& Demertzis, 2018, p. 412).

The possibility of transvaluation (rather than a mere diversion by elites of resentment) here is important as suggested by the focus of Salmela and Capelos (2021) on two parallel processes, as it may explain some of the complex and often contradictory ways in which groups such as non-voters and UKIP supporters seem to simultaneously desire and devalue possibilities (such as of being listened to by politicians; a point that is explored by Celis et al., 2021, in terms of "democratic dilemmas"). But in the accounts introduced above, shame is not identified as a driver of support for UKIP and Brexit. Salmela and von Scheve $(2017,2018)$ have focused on repression of personal shame and group identity distancing as key emotional mechanisms that underpin a reactionary political orientation. In Salmela and von Scheve's (2017) theoretical analysis, repression of economic shame about actual or anticipated loss of status is posited to transform the emotion into anger and resentment against a range of perceived threats to, or enemies of, oneself and one's groups (e.g., family, community, nation). Distancing from social identities that generate shame or humiliation combines with movement towards identities and attitudes that offer a more exclusionary, and potentially contemptuous and arrogant, group pride (Sullivan \& Day, 2019). This combination of societal and cultural positioning along with personal and communal experiences motivates a strong interest in anything 
that can turn things back to the way they were and fuels the expression of highly critical views of the current status quo. Further, Salmela and von Scheve (2018) speculate that a crucial distinction between reactionaryorientated populists on the right and left of politics, is that the former are not open to discussing sources of individual or group-based shame. This is where the double transvaluation possibility described by Salmela and Capelos (2021) offers a further insight worthy of rigorous empirical investigation: The ressentimentful individual seeks the recognition of others for the new self or social identity (which replaces the repressed shameful identity) through sharing of group-based emotions but also they "defensively suspect their peers of being deceptive" (Salmela \& Capelos, 2021, p. 200).

\section{Rationale for Studying Reactionary Orientations as Affective Practice}

Wetherell's (2012) affective practices approach systematically combines affect theory and emotion science in a way that works through the conceptual excesses of the latter and the measurement (i.e., operationalisation) limitations and experimental focus of the former. It incorporates insights from forms of emotion discourse research (e.g., "extreme case formulations"; Edwards, 1999) that emphasised what emotion words and statements "do" in everyday accounts but failed to examine their embodied features and practices. Citing examples from internet comments boards about politicians such as "If any MP had balls, they'd have paid for things out of their own pocket like y'know... ordinary people" (Wetherell, 2012, p. 72), Wetherell shows how the analysis of such postings is "a nice reminder of the flavour of ordinary affective meaning-making in one of its discursive public forms" (2012, p. 72). But it is the potential of a further "example of an affective practice of 'righteous indignation"" (Wetherell, 2012, p. 72) that guides the research described below. Wetherell states that within melancholic communities, "rhetoric and narratives of unfairness, loss and infringement create and intensify the emotion. Bile rises and this then reinforces the rhetorical and narrative trajectory. It goes round and round" (Wetherell, 2012 , p. 7). This brief analysis fits with the view that a reactionary orientation is not a defining, life-long personality trait; instead, it is a context-sensitive and practicebased "way of relating to the political world... strengthened, moderated, and superceded based on how citizens interact with their political environment" (Capelos \& Katsanidou, 2018, p. 1275; see also Billig's, 1978, 2014, analyses of fascism).

Accordingly, the aim for the current study is to investigate patterns of affective practice and related reactionary "felt utterances" (Wetherell, 2012) which are mentioned in or can be inferred from the practices and situations in which those affects are tried out, rehearsed, debated, regulated, shared and "sedimented" in longer term habitual and unreflective behaviour.
This approach highlights long-term emotion-related processes that explain a "build up" of resentment and bile, as well as the way victimhood can be experienced as righteous. But also Wetherell (2012) points out the conceptual problems that attend traditional dynamic psychoanalytic accounts and the way they draw "attention away from the organization and normative logics of the unfolding situated episode, context, interaction, relation and practice and on to a hidden, determining, individual, psychic logic instead" (Wetherell, 2012, pp. 133-134; see also Salmela \& Capelos, 2021). Her use of Billig's (1999) rethinking of repression is a useful reminder to focus research instead on the patterning of "actual everyday social relations" (Wetherell, 2012, p. 136) and investigating practices such as changing the topic and choosing to elaborate some views and neglect others. For UKIP supporters and non-voters this means exploring their stories and efforts to alter and change emotions that are personal or based on family or group identities as well as to examine how they recall, imagine, or anticipate occasions in which their experiences and emotions are shared and collective (Sullivan \& Day, 2019). Close investigation of manifestations of and talk about group-based emotions such as shame and pride in everyday life may therefore reveal important distributions of affective practices in social formations (Wetherell, 2012).

\section{Research Questions}

The study research questions were: 1) Do non-voters and UKIP supporters demonstrate resentment and ressentimentful affectivity in accounting for their combined anti-political stances?, 2) Can posited emotional mechanisms and repression of shame be inferred from people's research conversations and accounts of their practices?, and 3) What distinct patterns of embodied and situated affect-laden and emotion-related activityincluding "change backwards" (Capelos \& Katsanidou, 2018) affective practices-are evident in the interviews of non-voters and UKIP supporters?

\section{Method}

\subsection{Research Context}

In 2015, there were approximately 37 million eligible registered voters in England (Office for National Statistics, 2019) out of a possible UK total of 46 million voters (Gani, 2015). In the UK general election of that year, the registered voter turnout was $66.1 \%$ in England, which confirmed "a long-term decline in the willingness of voters to make it to the polling station" (Cowley \& Kavanagh, 2016, p. 416). Non-participation of people who are eligible to vote in national elections is a source of concern to parliamentary democracies because it indicates growing discontent with and disengagement from political processes. Another concern amongst established parties was the growth of the UKIP from a fringe, radical 
right-wing party in the 1990s (Ford \& Goodwin, 2014) to the party with the third highest number of votes$12.6 \%$ or nearly 4 million across the UK-in 2015 (but only one parliamentary seat). As Ford and Goodwin (2014) explain, UKIP profited from a decade of growing anti-European Union sentiment and from adopting a strategy that fused nativism and anti-Europe, anti$\mathrm{EU}$, and anti-immigration stances with radical right-wing mistrust of elites. In affective terms, UKIP was able to organise "contrasting emotional feelings...hope for the future and nostalgia for the past, feelings it associated with notions of patriotism, tradition, and 'Britishness'" (Cromby, 2019, p. 60). Given that non-voters were likely to be disengaged, mistrustful of the two main parties and attracted by a combination of hope and nostalgiainfused anti-political emotions that eventually became prominent in the EU referendum Leave campaign, combining this group with UKIP supporters arguably represented citizens of England with reactionary political orientations. These two groups represent supporters of "anti-preferences" such as anti-immigration and anti-EU preferences that Capelos and Katsanidou (2018) argue co-occur when they are more strongly related to proxies for reactionism; namely, a respect for tradition and an "aversion towards openness to change" (p. 1278; see also Celis et al.'s, 2021, analysis of focus groups with target groups such as Yellow Vest protestors who are likely to experience resentful affect). Goodwin (2015) noted that after the 2015 election, UKIP's "continued prominence in British politics rests not only on the outcome of the forthcoming referendum on Britain's EU membership but also the salience of immigration, which since the general election has risen to record levels" (Goodwin, 2015, p. 15). At that time, he also pointed out that of the 10 to $15 \%$ of the population who support UKIP's twin opposition to the EU and immigration: "This is likely to fuel support for the 'Leave' camp at the referendum, although it may not be enough to carry the Eurosceptics over the line" (Goodwin, 2015, p. 15). Subsequent analysis of the EU referendum result indicated that mobilising non-voters was decisive in winning a small majority for Leave. The participants in this study should therefore provide insights into why some non-voters eventually contributed to the $72.6 \%$ turnout for the 2016 EU referendum, a level of voting participation "higher than any UK general election since 1992" (Dempsey \& Johnston, 2018, p. 10).

\subsection{Participants, Recruitment, and Interviewing}

Ethical approval for the study was provided by the Ethics Committee of the Centre for Research on Psychology, Behaviour and Achievement, Coventry University. Participants were recruited for qualitative interviews on the basis of prior participation in a pre- and postelection Qualtrics survey of 1400 citizens of England eligible to vote in the 2015 election, distributed online by a market research company in the week before and the month following the election date of May 7th 2015. Demographic information and participant details including national identity and ethnic identity items informed by previous electoral research (Wyn Jones et al., 2013), are described in Table 1. Participants who did not vote in the election and participants who had voted for UKIP were selected from the whole sample, and people from both groups who gave permission to be contacted were invited to take part in an interview. This resulted in a study sample of 10 non-voters ( 9 female, 8 male, age range $22-75$ years, average age 39.3 years) and 19 UKIP voters ( 10 female, 9 male, age range $23-84$ years, average age 50.8 years). Interviews were conducted by telephone by the lead author and four research assistants (see Acknowledgements) in June 2015. The interviews took between 20 minutes and 50 minutes (with participants reimbursed at a fixed amount higher than the minimum wage). The same interview schedule was followed by all interviewers, but they were also able to ask followup questions to elicit more detail about the situated circumstances in which people "do and feel" politics in their daily lives. Interviews were recorded as digital files for subsequent deidentified verbatim transcription.

\subsection{Analytic Strategy and Reflexivity}

A critical realist case study framework was adopted in which interviews were used to identify and infer patterns of affectivity in the situated circumstances of individuals (Sullivan, 2018). The study was concerned with emotionladen or oriented forms of intertwined discourse and embodied action that can potentially become habitual or "sedimented" over time (Wetherell, 2012). The affective practices theoretical framework which has been used for emotion-focused fieldwork (e.g., exploring experiences in relation to national days; see Wetherell et al., 2020) was combined with in-depth qualitative interviewing and a reflexive thematic analysis (Braun \& Clarke, 2020). Given the contentious nature of some of the political issues discussed, phone interviews provided freedom and anonymity from the demands of face-to-face conversation. While people's facial expressions and gestures could not be analysed, the distance of a telephone interview and the adoption of a naïve, interested, and gentle exploratory stance by the interviewers may have contributed towards the candidness of some interviewees' conversation (e.g., some participants expressed thanks for being listened to and others even described the interviews as "therapeutic"). The interviewers were attuned to the possibility that individuals who were being interviewed as potential reactionaries on the right of politics might experience personal and group-based shame in relation to their circumstances and to being interviewed by political "experts." Reflexivity concerns focused also on how people with reactionary orientations were identified and whether the theoretical and practical basis for this designation could feed back into the pathologisation of people who oppose mainstream politics. It was crucial 
Table 1. Interview participant information.

\begin{tabular}{|c|c|c|c|c|c|c|c|c|c|c|c|c|c|c|}
\hline Pseudonyms & NM1 & NF1 & NF2 & NM2 & NM3 & NM4 & NF3 & NF4 & NM5 & NF5 & UF1 & UF2 & UM1 & UM2 \\
\hline Age & 20 & 22 & 42 & 75 & 27 & 21 & 35 & 47 & 55 & 49 & 68 & 84 & 36 & 70 \\
\hline Gender & Male & Female & Female & Male & Male & Male & Female & Female & Male & Female & Female & Female & Male & Male \\
\hline $\begin{array}{l}\text { Location } \\
\text { by county }\end{array}$ & Bedfordshire & $\begin{array}{l}\text { Greater } \\
\text { Manchester }\end{array}$ & Norfolk & Somerset & $\begin{array}{l}\text { Worcester- } \\
\text { shire }\end{array}$ & $\begin{array}{l}\text { Greater } \\
\text { London }\end{array}$ & $\begin{array}{l}\text { Greater } \\
\text { London }\end{array}$ & $\begin{array}{l}\text { Nottingham- } \\
\text { shire }\end{array}$ & Essex & $\begin{array}{l}\text { Greater } \\
\text { London }\end{array}$ & Wiltshire & Wiltshire & $\begin{array}{l}\text { Greater } \\
\text { Manchester }\end{array}$ & $\begin{array}{l}\text { East } \\
\text { Midlands }\end{array}$ \\
\hline $\begin{array}{l}\text { National } \\
\text { identification }\end{array}$ & $\begin{array}{l}\text { British } \\
\text { and } \\
\text { English }\end{array}$ & $\begin{array}{l}\text { British } \\
\text { and } \\
\text { English }\end{array}$ & $\begin{array}{l}\text { British } \\
\text { and } \\
\text { English }\end{array}$ & English & $\begin{array}{l}\text { British } \\
\text { and } \\
\text { English }\end{array}$ & British & $\begin{array}{l}\text { British } \\
\text { and } \\
\text { English }\end{array}$ & English & $\begin{array}{l}\text { British } \\
\text { and } \\
\text { English }\end{array}$ & $\begin{array}{l}\text { British } \\
\text { and } \\
\text { English }\end{array}$ & British & English & $\begin{array}{l}\text { British } \\
\text { and } \\
\text { English }\end{array}$ & British \\
\hline $\begin{array}{l}\text { Ethnic } \\
\text { Identity }\end{array}$ & English & $\begin{array}{l}\text { British } \\
\text { and } \\
\text { English }\end{array}$ & English & English & $\begin{array}{l}\text { British } \\
\text { and } \\
\text { English }\end{array}$ & Pakistani & $\begin{array}{l}\text { British } \\
\text { and } \\
\text { English }\end{array}$ & English & English & English & English & English & $\begin{array}{l}\text { British } \\
\text { and } \\
\text { English }\end{array}$ & British \\
\hline $\begin{array}{l}\text { Previous } \\
\text { voter }\end{array}$ & No & Yes & No & Yes & No & No & Yes & Yes & Yes & Yes & Yes & Yes & Yes & Yes \\
\hline $\begin{array}{l}\text { EU Ref } \\
\text { participation }\end{array}$ & Yes & Unsure & No & Yes & No & No & No & Yes & Yes & No & Unsure & Yes & Yes & Yes \\
\hline $\begin{array}{l}\text { Intended EU } \\
\text { Ref vote }\end{array}$ & Leave & Unsure & Leave & Unsure & Leave & Leave & Leave & Leave & Leave & Unsure & Leave & Leave & Leave & Leave \\
\hline
\end{tabular}

Note: $\mathrm{NF}=$ non-voter female, $\mathrm{NM}=$ non-voter male, UF = UKIP voter female, UM = UKIP voter male. 
Table 1. (Cont.) Interview participant information.

\begin{tabular}{|c|c|c|c|c|c|c|c|c|c|c|c|c|c|c|c|}
\hline Pseudonyms & UF3 & UF4 & UF5 & UF6 & UF7 & UM3 & UM4 & UM5 & UF8 & UM6 & UM7 & UM8 & UF9 & UM9 & UF10 \\
\hline Age & 65 & 50 & 59 & 23 & 50 & 66 & 70 & 54 & 47 & 67 & 66 & 25 & 23 & 62 & 48 \\
\hline Gender & Female & Female & Female & Female & Female & Male & Male & Male & Female & Male & Male & Male & Female & Male & Female \\
\hline $\begin{array}{l}\text { Location } \\
\text { by county }\end{array}$ & $\begin{array}{l}\text { South } \\
\text { Yorkshire }\end{array}$ & $\begin{array}{l}\text { Greater } \\
\text { Manchester }\end{array}$ & Norfolk & Lincolnshire & Dorset & $\begin{array}{l}\text { Cambridge- } \\
\text { shire }\end{array}$ & $\begin{array}{l}\text { Oxford- } \\
\text { shire }\end{array}$ & Cheshire & $\begin{array}{l}\text { Greater } \\
\text { Manchester }\end{array}$ & Hampshire & $\begin{array}{l}\text { Mersey- } \\
\text { side }\end{array}$ & Lancashire & Norfolk & Kent & $\begin{array}{l}\text { Greater } \\
\text { London }\end{array}$ \\
\hline $\begin{array}{l}\text { National } \\
\text { identification }\end{array}$ & English & British & English & English & English & $\begin{array}{l}\text { British } \\
\text { and } \\
\text { English }\end{array}$ & English & $\begin{array}{l}\text { British } \\
\text { and } \\
\text { English }\end{array}$ & British & British & $\begin{array}{l}\text { British } \\
\text { and } \\
\text { English }\end{array}$ & British & British & English & English \\
\hline $\begin{array}{l}\text { Ethnic } \\
\text { Identity }\end{array}$ & English & English & English & English & English & $\begin{array}{l}\text { British } \\
\text { and } \\
\text { English }\end{array}$ & English & English & British & English & British & $\begin{array}{l}\text { British } \\
\text { and } \\
\text { English }\end{array}$ & British & English & English \\
\hline $\begin{array}{l}\text { Previous } \\
\text { voter }\end{array}$ & Yes & Yes & Yes & Yes & Yes & Yes & Yes & Yes & Yes & Yes & Yes & Yes & Yes & Yes & Yes \\
\hline $\begin{array}{l}\text { EU Ref } \\
\text { participation }\end{array}$ & Yes & Yes & Yes & Yes & Yes & Yes & Yes & Yes & Yes & Yes & Yes & Yes & Yes & Yes & Yes \\
\hline $\begin{array}{l}\text { Intended EU } \\
\text { Ref vote }\end{array}$ & Leave & Leave & Leave & Leave & Leave & Leave & Leave & Leave & Leave & Leave & Leave & Leave & Leave & Leave & Leave \\
\hline
\end{tabular}

Note: $\mathrm{NF}=$ non-voter female, NM = non-voter male, UF = UKIP voter female, UM = UKIP voter male. 
to look for examples that disconfirmed themes and to report the results in accordance with criteria for good quality qualitative research (Levitt et al., 2018).

\section{Results and Discussion}

Consistent with the account of a reactionary orientation, and analogous to Billig's $(1978,2014)$ criticisms of authoritarian personality trait explanations of supporters of fascism, participants in this study combined subjective positions with enactments and embodiments of personal and social identities which often resonated with the circumstances of their communities. As outlined below, the themes identified in the combined post2015 election interviews were: 1 ) sharing "condensed" complaints and expanding upon grievances about politics, including distrust, and enacting resentment about not being listened to (for in-depth examples, see Celis et al., 2021); 2) orienting towards shameful and purported shameless racism related to the new "righteous victim" identity; and 3) transvaluation, nostalgia, and change backwards. The latter two themes are presented with exemplars and interpreted in terms of multipleoften competing - fragmented frameworks and explanatory accounts, including critiques of explanations focusing on emotional contagion, pathologisation of the working class, and the role of collective nostalgia in support for populist ideas.

\subsection{Immigration Shame, Shamelessness, and Ressentiment}

As indicated in Table 1, both non-voters and UKIP supporters had overlapping anti-political stances and were broadly in agreement that the UK should leave the European Union. Given that many non-voters expressed a dislike for all political parties and elites because they did not listen to them and did not care about them, there were points of commonality with UKIP voters in terms of how they accounted for their opposition to migrants and free movement within the European Union. For example, one male non-voter noted:

NM5: I'll vote because I think that Europe is part of the problem, we give them all that money and for what but I don't agree with UKIP and those lot they stand and then don't go, what's the point in that we don't vote for people to do nothing, they are just the same as the Euro bureaucrats taking the money and doing nothing aren't they?

$\mathrm{NM} 2$ focused on problems with all the political party leaders, and stated the main problem was that "I'm not given a reasonable choice of people to vote for. I don't want Milliband, I don't want Cameron, I don't want Clegg, I don't want Farage." What many participants agreed on, however, was the liberating and empowering antiimmigration and anti-EU message promoted by Farage and UKIP: "He speaks the truth. He speaks a lot of what people think, I think, but are too scared to say. I think he sticks up for a lot of people and what they're too scared to say out in public" (UF9).

With UKIP supporters, immigration consistently evoked the shame connected with racism. Initially some participants passed over the topic, as in the following conversation:

NM1: Erm I think the younger I was the more positive I was about politics, keen, fresh.

\section{I: And now?}

NM1: Probably just disillusioned with it, it's not making a lot of difference to England with all these immigrants.

For non-voters and UKIP supporters who were Eurosceptics mostly, but not exclusively, because they were opposed to immigration, a key challenge was how to orient towards potentially shameful charges of racism connected with the populist party that supported a "new social self"; namely, that UKIP were known for "talking against immigration, they are taken to be racist" (UM3). Where it was the explicit subject of conversation in the research interviews, racism was often oriented towards as a serious issue potentially laden with shameful thoughts and feelings. A wide range of discursive strategies was evident in the interviews including defensive denial at the suggestion of group-based shame connected with supporting UKIP (e.g., "Absolutely not. I haven't got a racist bone in my body," UM2) through to acknowledgement that UKIP contained some extremists and racists.

One participant summed up the kind of affective practices that made it difficult for many people to say openly that restricting immigration was UKIP's primary appeal:

UF10: I know a lot of people say it's politically incorrect to say it, and again this is... social err sort of training almost, over the years. We're all kind of... I'm not and neither are any of UKIP racist, it not a racist thing, because you are led to be believe you are a horrible person if you think "well actually, you know, we're buckling at the seams."

Participant UF1 argued that she wanted to have:

A points system like Australia, you know, I mean we must have people here who are going to contribute and make our country richer in every way... It's not you know sort of just banning all foreigners [laughs] you know, I'm not xenophobic, but erm ah now did your questionnaire talk about xenophobia.

The hesitation here suggests the kind of psychic disruption that has been identified previously as a plausible marker of shame in conversation (Probyn, 2005). 
It was particularly evident in the conversations with UKIP voters that many oriented towards shameful features of support for UKIP through denying they were racist or xenophobic and normalising racist individuals within the party (i.e., such exceptions were argued to be present in all parties). Some non-voters seemed to feel that their lack of knowledge of political matters somehow marked them out as lesser citizens; this was noted frequently when discussing the elites and experts they resented. Analogously, UKIP supporters appeared to demonstrate that the charge of racism was another way in which they were made by elites to feel bad about their already difficult individual or collective circumstances. In response to the question, "Do you think politicians understand what is happening in your area?," NM3 provided an example that can be identified as discriminatory and expressing prejudice towards Eastern Europeans but also revealed resentment that politicians don't face these challenges: "No, like all the Poles coming in, well it's not just the Poles any more is it, it's all eastern Europeans, nobody does anything to stop it." The unnamed "nobody" here was explicitly identified in other interviews as politicians.

NM3 demonstrated how the ordinary experiences of two groups many of the participants disliked, Eastern European migrants and people of a Muslim faith, were presented as challenging and changing aspects of immigration that politicians did not have to deal with: "They are removed yeah, they don't have foreigners running all over their area, 70 different languages in their kids' school, not singing carols in case you upset the Muslim kids, halal meat everywhere, what's that for anyway halal?" Combining these accounts indicates an affectivediscourse repertoire that can be drawn upon when discussing the state of the country and which shows that both UK political elites and Europeans can be described as unconcerned and even happy about the migration of, for example, Eastern Europeans to the UK (i.e., implying not only that a range of others do nothing about their concerns but also that some others actively want this to happen). In the example above, NM3 conformed with an explanation of ressentiment in which there is an affective dilemma of anger (potentially motivating action) and powerlessness to do anything about this that has become habitual or sedimented over a long time.

In contrast to accounts focusing on economic shame outlined by Salmela and von Scheve (2017), supporters of right-wing reactionist stances would be expected to react with anger to defend their illiberal political views or cover a sense of shame or failure for holding them. They would also be expected to respond this way to feelings of not being listened to and of being devalued by politicians (i.e., in comparison to migrants, who were often described by right-wing reactionists as "jumping the queue" and competing for limited resources). This study supported such explanatory accounts but also found that some participants advocated more openly aggressive and extreme views that might have been the product of the repression of individual economic and racism-related shame (Salmela \& von Scheve, 2017). For example, NM4 said he talked about political issues mainly with his mates, raising the issue of asylum seekers in France, who were "trying to come over, that's not right and nobody is doing anything, the French just want to get them on trains over here, get rid of them like." UF7 reported social media discussions about "filling in the channel tunnel" to prevent refugees walking through it: "These so-called refugees are completely false and they should get lost," adding that "they're not refugees, they're economic migrants." Instead of trying to understand their aims in coming to the UK and any potential for them to contribute positively, she dismissed this group as only aiming to "come into this country and try to ruin it."

For one participant, being in public spaces in the presence of people not speaking English was deeply uncomfortable, raising further concerns and grievances that were ultimately connected with a loss of national identity:

UF9: I was only shopping today and there was, I think they might have been Polish but they were speaking foreign, looking at you funny but you don't know what they're talking about. They could be talking about you, I don't feel comfortable, I feel like I'm in a foreign country, I'm not in Britain, I'm not in an English place, I feel like I'm in Poland somewhere, I'm not in the UK when I'm out and about.

Such accounts were related to a sense of loss that included the threat of a loss of identity and being pushed out by others, and it was usually accompanied with a familiar lament that it was shameful that politicians did not do anything about this. Instead of blaming others, however, several participants noted the loss of an imagined positive national community that appeared to prefigure the theme of transvaluation that is examined in Section 6.2: "We seem to have lost the knack of coping now" (UF2).

In this context, an alternative conceptualization of repression is helpful; namely, that shame is not unconscious but rather occurs as everyday interaction "reproduces immoral temptations, which are routinely resisted and repressed" (Billig, 1997, p. 140). The interviews allowed for some participants to say things which usually remain unspoken, except when sharing with likeminded others. Long-held racist and xenophobic views were usually rejected in favour of a positive in-group account that did not fully address the ambivalence that often comes with persistent prejudice (e.g., combinations of feelings of warmth and unspoken or repressed negative judgements of others as less competent, that make racial prejudice resistant to change; see Dixon et al., 2012). In place of acknowledgement of racism "in us," many participants reiterated the consequences of uncontrolled immigration: 
UM2: And the NHS is crumbling, schools can't cope, housing is in a terrible state because we haven't got enough, because there are millions and millions of people coming into the country. It's not racist to say stop.

Here evaluating grievances about immigration through the lens of prejudice feeds into a sense of resentment and powerlessness to be able to say something. The lack of open discussion has arguably resulted in a desire for leaders who will speak openly on such issues, a form of empowerment that shares shame and alleviates any guilt about the consequences of widespread restrictive or punitive control of "immigrants" (including asylum seekers, refugees and other migrants). UKIP, for example, created opportunities for a kind of liberation from repressed economic shame, older shame-attracting identities (e.g., some occupational identities as discussed by Salmela \& von Scheve, 2017). However, being against Europeans and the EU did not appear to create a sustainable "noble and superior" social self (Salmela \& Capelos, 2021).

Participants' emotion-laden references to many people sharing these views provide a kind of cover against the individualising effect of the charge of shameful racism associated with anti-immigration stances. It is telling that when evaluating claims about good and bad immigrants, one participant stated:

So it's really difficult to find your way through the mire, you welcome the people who are prepared to work and abide by our rules, it's not that hard for god's sake, but we ought to be able to say no to people we don't want." (UF4)

Ultimately, therefore, racism was re-presented as an issue of being able to decide as a group who is acceptable while also avoiding as much of the "mire" attached to debates about immigration. Mixed feelings about supporting UKIP - and a sense of a defensive suspicion about one's populist peers (see Salmela \& Capelos, 2021)-was indicated by a participant who was voting for them on a single issue of opposing the HS2 railway:

UF4: You know discussing membership or not of the $E U$, is more palatable than discussing curbs on immigration but I have a feeling that the majority of supporters of UKIP are probably in it from the immigration point of view which I think is a bit of a shame as it gives is somewhat a negative image and it makes you perhaps feel a little awk-embarrassed to associate yourself with it.

Thus, even with her limited connection to UKIP, for this participant there was a strong sense of being associated with a group which struggled to avoid the shame of a morally indefensible position on immigration.

Further examples showed how willing some participants were to express deeply ambivalent, affective dilem- mas around the "common sense" view that "a country should look after its own citizens before they start looking after imports" (UM2). Here the participant failed to realise that talking about "imports" is a dehumanizing way to address the potential contributions-and complex humanitarian and other needs-of economic and non-economic immigrants, asylum seekers, and refugees. UF6 went further and imagined being able to close the borders completely before realising she would need to settle for something less than this fantasy:

I'd like the borders to always be shut off, but the realistic approach would be just more control. Obviously if you stay in the EU you're not really going to be able to control the European citizens coming in because they're allowed to.

Another participant suggested that while the referendum was still a year away, there was already a shared sense of what leaving the EU would mean: "Yeah, yeah cause then they can say 'tatty bye' to a lot of people, shut the door and a lot more, then we might have some jobs, we have some schools and classes that are not overfull" (UF5). These overtly aggressive and dehumanizing stances demonstrated not only a shamelessness about leaving the EU in order to exclude a wide range of migrants, but also devaluation of an awareness of the shared basic concerns of people (e.g., to belong in and contribute to a place) and the value of a global solidarity.

A further shame sub-theme was the role of the EU in allowing and even intentionally causing humiliation of the British people. NM3 expressed anger about immigration and his powerlessness to do anything about it through traditional political practices. He positioned "the rest of Europe" as being happy that migrants were preferring Britain over their countries, while also devaluing voting as a means to be heard on the topic:

I don't, I'm not going to vote. Europe is full of Eastern Europeans coming here, they all want to come here to use the NHS, take the jobs and the rest of Europe doesn't care, as it doesn't concern them, they're glad they're coming here and not there." (NM3)

Europe and the EU were represented as agents that felt positive about the control and power that they had over the UK: "I mean we almost have to get permission every time we want to do anything, change anything. Brussels has to authorise it, well that's ridiculous." UF9 imagined this trend continuing, especially if people voted to stay in the EU:

It'll be more of what we've got already. More immigration coming over, more people taking our jobs that nothing will be Britain anymore. We'll be classed as the EU, we won't be our own country, we can't do anything unless we you know have to ask the EU people first if we can do this, do changes and I think if 
we're our own country we should be able to do and change whatever we like.

The affective dilemma of a potential future shameful loss of identity and control contrasted with the desire still for a positive sense of self-worth and even to return to a previous position of power. Ostensibly eschewing an anti-European stance based on nationality and general xenophobia, NM2 initially presented himself as open to collaboration with the EU: "I'm not a great patriot, so I'm not going to say ooh we don't want to be mixed up with Europeans." However, he went on to express a fundamental ambivalence which was eventually captured by a less open sense of "tolerance" and a stance consistent with the phrase "Take back control": "I don't mind being mixed up with Europeans, but I don't want them dictating to me how I should and shouldn't live" (NM2).

\subsection{Transvaluation, Nostalgia, and Change Reactionist-Style}

The account presented thus far suggests that the details of anti-EU feelings are usually passed over and, if stated in public conversation, are oriented to as something that others will find unacceptable or intolerable. An individual neo-liberal subjectivity that implies that we are responsible for the circumstances that we live in is deeply unpleasant to acknowledge: Blaming others can be an attractive alternative because it presents an opportunity to exercise a sense of agency and to look for sources of positivity about one's demeaned, devalued, or humiliated identity. It is possible then to find examples of Salmela and Capelos's (2021) parallel processes of transvaluation which were at different stages of being "worked through"; namely, devaluation of values that were previously regarded as important (e.g., community values, equality, national unity). Devaluation of the UK was evident in descriptions of the country as a "dumping ground for everywhere else" (UM6), "I just don't think there's anything to vote for anymore" (NF4), and "I just think the whole system stinks, it's rotten to the core. Not just politics, everything in this country stinks" (NM2). Arguably, freedom of movement was also devalued by citizens when they were willing to sacrifice this for themselves or for young people to limit immigration mostly, but not exclusively, from Europe.

Reactionary "desire for change backwards" and opposition to politicians trying to maintain the status quo contrasted with calls for radical political change, expressed by some participants as the need to "get rid of the lot we've got" (NF4) and to "start again with a different type of people in politics" (NM2). Many non-voters were despondent about the possibilities of achieving change through politics but were open to opportunities such as the 2016 referendum; while many UKIP voters felt that an anti-establishment party might be the best means to achieve the kind of change they wanted. Explicit discussions of change appealed to a widely shared view of a desirable past which many participants eventually connected with a need to leave the EU: "There's an awful lot of people who remember pre-war, like me, who feel very strongly that this isn't a country that we know any more" (UF2). Others described areas of cities and places like East London as irrevocably changed: "You go there and you don't recognise the place anymore, you feel like a foreigner in your own country" (UM9). UM5 spoke about these changes with a mixture of nostalgia and dismay:

When you get to my age you remember when you lived in an area and everybody was in the same boat, there was that community, if you like, you know, can I borrow a cup of sugar from your neighbours, that sort of thing. Now the gap is so huge between the haves and have nots.

The connection between a retrospective focus and leaving the EU becomes clearer in statements from older participants who associated joining Europe with the beginning of a period of British decline:

Before we were in Europe this country was getting on its feet and it was in a good state after the war, and we got in at a good time. Until we got into Europe and we saw the decline start to start, and that's the reason l'd like to see us out of it. (UM4)

The sense of loss is also evident in a response to the follow-up question: "So for you, the things that are kind of just gone downhill are linked to Europe rather than the banking crisis?," to which UM4 replied: "We're quite a clever race, and we're quite good at what we do and our manufacturing and all that" but also noted:

I mean we lost steelworks and stuff like that, our car plants all gone. We used to produce the best cars in the world, the steel was took all over the world and it's all gone now, and you know we've lost it all.

UM2 concurred: "I feel very strongly about being in the European Union, I think that it's holding our country back quite dramatically."

Nostalgia about one's nation implies a positive experience of reflecting upon a time when things were better. While some of the examples above suggest a collective nostalgia, remembering what was good about the past was felt as a loss in the present. The NHS, for example, was a subject of both nostalgia and concern to many participants, but this does not appear to fit with a reactionary account of populism except where fear and anger about its decline could be traced to neglect by UK politicians and a potential monetary benefit of leaving the EU. Moreover, while immigrants were praised for their role in the NHS, many participants argued that ultimately the "way we are carrying on with the NHS, we won't have one anyway, not unless we get out of Europe 
we won't" (UM4). The notion of an anti-establishment career (Kemmers et al., 2016) suggests that the resentful feelings of citizens combine with experiences of negatively changing life circumstances. Reacting angrily to the pace of social change and feeling nostalgic about the past are affects that sediment over time in a way that is consistent with findings that support for populist views increase with age.

In contrast, the seven participants in this study under 30 years old might be expected to be less likely to combine anti-politics stances with a desire to change things back to a previous, better time, when their community or the country was perceived in more positive or even "glowing" and mythologised terms. Family conversations provided some participants with a sense of a better past that had been shared with them as a younger generation. As a result, UF9 was clear about what needed to be done:

We should get out definitely, be our own country. What we used to be. That's all gone pear shaped since we joined the EU. Years ago, my dad always told me all the time, how things are so different and now he doesn't even recognise the country anymore. It's not what it was, not at all.

From an older person's perspective, UM4 described feeling sorry for younger people as things get progressively worse in the country: "'Cause I feel sorry for the youngsters now who are going to have to put up with what they are going to get. And I think this world is on its way backwards not forwards." Somewhat confusingly, this participant's vision was more about going back, rather than forward towards more social change, because by leaving the EU he hoped that the UK would begin to reverse the problems caused by "into Europe":

UM4: Things just haven't worked, I mean they have changed this country to something which is absolutely useless. I mean put it this way, it's gone back again. Before we went into Europe, this country was really getting on its feet. I mean it took a long time after the world war for things to get right and it seemed to get more and more right and settled and in a straight line if you get my meaning, we were on a balance.

Desire for "backwards focused" change was also articulated in the anticipated positive outcomes of leaving the EU: "I think we'll be a stronger country I think yeah we'll just be stronger and have more worldwide trade and more English can work more jobs and hopefully get the country back to what it used to be" (UF9). This sense of getting the country "back to what it used to be" encapsulates the sense of reactionary change, as contradictory as this can sound, because it is not literally about restoring the past. Change backwards by leaving the EU would also mean, "We'll be back to being known as being Great Britain, and the others [in the EU] aren't great without
Britain. I think we'll get our name back, definitely" (UF9). UM5 who said he was against the EU "when we first went into all this," also remarked:

My thoughts haven't changed. It goes back to we're an island and we're proud of being an island and independent, we don't want to be ruled by the masses. You know we managed for hundreds of years without that so let's carry on.

Against a narrated background of loss of past national strength, greatness, and previous collective coping abilities, several participants emphasised restoring national sovereignty as a benefit of leaving the EU:

I think we should be an independent European country away from Brussels. We shouldn't let Europe dictate their rules to us when we've always been a force to contend with you know, we are a world power, we should just stay separate you know. (UM8).

In this situation, leaving the EU could refocus efforts on making "Britain as good as it was, I don't know, 40,50 years ago, and we have declined, I think we've become too reliant on other countries when we don't need to from an economic point of view" (UF10). They imagined a reversal of the situation under the EU from being dictated to-and therefore being humiliated as a nation-to being able to dictate to others:

UM1: Yeah, currently, I don't think it is British identity, its more European and that's one of the main reasons I want to come out, 'cause I want to revert to back to being British and English, like you say erm and at the moment I don't believe we are, we're sort of being told by other countries what to do really, when it should be the other way around.

The excerpt clearly catches the reactionary focus on change backwards to a normal British-first identity: "Because then you're British, you, you, you're not European, 'Ah, you're part of the EU,' no you're British and that's it. You go back to what you were, normal thing, which is you're British" (UF1 with imagined discussant in single quotation marks). The example also shows how this can be achieved through affective discursive practices in which undiscussed shame and inferable humiliation by the EU are replaced with a collective or hubristic pride based on superiority to, or desired dominance over, others.

\section{Conclusions}

The ressentimentful account of a reactionary orientation among supporters of populist ideas, parties, and movements is promising, but relatively untested. In this article, the concept of reactionary affective practices was introduced to explore how affects or emotions such as anger, 
resentment, and fear combine with other emotions, and change over time to become intense feelings towards groups regarded as being opposed to one's own interests. Three additional features that have been identified in the political psychology literature were addressed: 1) support for a combination of anti-political stances (e.g., against voting, or for UKIP and for leaving the EU and being opposed to immigration), 2) a potential role for economic shame-repressing ressentiment, the ways in which shame became attached to UKIP and anti-EU views primarily through the possibility of racism (rather than simply being the product of a previously existing or dormant racism as many people oriented towards this), and 3) a focus on the affective complexity of reactionary change backwards (i.e., that it is not a simple desire to recreate the past, a feeling of collective nostalgia or widespread collective narcissism).

On the first issue, the analysis of interviews with English non-voters and UKIP supporters showed the importance of participating in ordinary activities of careful or limited sharing of grievances over time in forming the view not only that it would feel right to leave the EU, but also sensed that many others in their communities shared these feelings. By examining the affective practices of people around the time that the EU referendum was announced, it was possible to show how strongly many already felt about immigration, elite politicians, and the EU as the agent primarily responsible for social and political change, including the loss of industries, a decline in post-war prosperity, a humiliating curtailment of autonomy and independence, and a reduced role on the world stage. The benefit of focusing on reactionary affective practices-rather than reactionism as a discourse, general stance, or personality trait-was that the "demand side" of support for the populist policy of leaving the EU could be examined in the period before the official start of the referendum campaign (e.g., including attempts to link leaving the EU with saving money that could be redirected towards "our NHS").

Shame-repression and long-term ressentiment were examined by looking for instances where anger was used to cover (or condense) feelings of shame, or humiliation stemming from the neglect of UK politicians and the imagined enjoyment of the UK's predicament by Europeans or the EU. While many people spoke of losses and demonstrated suspicion that the right-wing populist anti-immigration politics of their populist peers could be criticised as racist, discriminatory, uncaring, and shameful; nevertheless extreme, aggressive, and dehumanizing attitudes were presented in a defiant, shameless manner. Some of these stances seemed unlikely to bear much discussion or criticism (i.e., which might have allowed shame to re-experienced), or been described in terms of the desire of the other to inflict humiliation. There was also evidence of the transvaluation of previous values and identities, but the parallel process of adopting a hopeful and potentially influential antiEU stance was often experienced as a highly ambivalent embodied affective dilemma, even though it might ultimately provide the means to restore pride in a British or English identity.

Our conversations also revealed nostalgia for a relatively prosperous post-war period that some participants wanted to return to, and others felt could be achieved again if the humiliating, controlling, and restricting role of the EU could be done away with. These findings extended Salmela and von Scheve's (2017) analysis of the repression of economic shame and showed how many participants combined a felt need to leave the EU with other anti-political stances. Older relatives had shared their memories with younger family members who had experienced neither the beginning of the European Market, nor Britain as a great country leading the world, dictating to others, having less diversity, being "less full," and with an NHS system that was able to "look after our own."

The affective practices focus on everyday forms of sedimentation shows potential to flesh out Cromby's (2019) Vygotskyan account of Brexit in terms of condensed and internalized dialogical emotions as well as the repetition of feelings of organisation over time that eventually "come to include feelings of knowing that leaving the EU is desirable" (Cromby, 2019, p. 65). The analysis avoided pathologising people who supported leaving the EU and any emphasis on "the gullibility of ordinary people as well as their xenophobia" (Walkerdine, 2020, p. 144). Regarding shame repression and ressentimentful affectivity, there was evidence of a wide range of orientations towards the shame of being against immigration, especially when enacted in a dehumanising and aggressive manner. Further research on the contribution of reactionary orientations to political populism should focus on: instances of transvaluation of previously shared values, ideals and identities, deep ambivalence around humiliated and potentially restorable British and English identities, defensive enactments of right-wing aggressive and dehumanizing views, connections with widely shared emotions in people's communities (e.g., widespread feelings of betrayal, etc.), and experiences of collective pride or hubris.

As a final point, it is vital that further work uses additional methods of rich data collection (e.g., ethnography, walk-along interviews, video analysis) to explore the variety of reactionary affective practices on both the right and left of populist politics. Telephone interviews should be supplemented by approaches that can examine the patterns and flows of emotional activity in the private and public lives, spaces and practices in which participants and specialist groups (e.g., Yellow Vest protestors, Alternative für Deutschland supporters) do reactionary politics.

\section{Acknowledgments}

Thanks are extended to Dr. Su Jones, Dr. Nathan Kerrigan, L. J. Potter, and Dr. Philippa Carr for assisting 
with interviewing and transcription as researchers in the Identities and Resilience in Communities and Organisations team of the former Centre for Research in Psychology, Behaviour and Achievement, Coventry University. Dr. Chris R. Day proofread an earlier draft and Terri Sullivan provided proofreading of the final manuscript.

\section{Conflict of Interests}

The author declares no conflict of interests.

\section{References}

Billig, M. (1978). Fascists: A social psychological view of the national front. Harcourt Bruce Jovanovich.

Billig, M. (1997). The dialogic unconscious: Psychoanalysis, discursive psychology and the nature of repression. British Journal of Social Psychology, 36, 139-159.

Billig, M. (1999). Freudian repression: Conversation creating the unconscious. Cambridge University Press.

Billig, M. (2014). Fascism. In T. Teo (Ed.), Encyclopedia of critical psychology (pp. 687-690). Springer.

Braun, V., \& Clarke, V. (2020). One size fits all? What counts as quality practice in (reflexive) thematic analysis? Qualitative Research in Psychology, 18(3), 328-352. https://doi.org/10.1080/14780887. 2020.1769238

Busher, J., Giurlando, P., \& Sullivan, G. B. (2018). Introduction: The emotional dynamics of backlash politics beyond anger, hate, fear, pride and loss. Humanity \& Society, 42(4), 399-409.

Capelos, T., \& Demertzis, N. (2018). Political action and resentful affectivity in critical times. Humanity \& Society, 42(4), 410-433.

Capelos, T., \& Katsanidou, A. (2018). Reactionary politics: Explaining the psychological roots of anti preferences in European integration and immigration debates. Political Psychology, 39(6), 1271-1288.

Castanho Silva, B., Jungkunz, S., Helbling, M., \& Littvay, L. (2020). An empirical comparison of seven populist attitudes scales. Political Research Quarterly, 73(2), 409-424.

Celis, K., Knops, L., Van Ingelgom, V., \& Verhaegen, S. (2021). Resentment and coping with the democratic dilemma. Politics and Governance, 9(3), 237-247.

Cowley, P., \& Kavanagh, D. (2016). The British general election of 2015. Palgrave Macmillan.

Cromby, J. (2019). The myths of Brexit. Journal of Community \& Applied Social Psychology, 29, 56-66.

Dempsey, N., \& Johnston, N. (2018). Political disengagement in the UK: Who is disengaged? (Briefing Paper no. CBP-7501). House of Commons Library.

Dixon, J., Levine, M., Reicher, S., \& Durrheim, K. (2012). Beyond prejudice: Are negative evaluations the problem and is getting us to like one another more the solution? Behavioral and Brain Sciences, 35(6),
411-425.

Droste, L. (2021). Feeling left behind by political decisionmakers: Anti-establishment sentiment in contemporary democracies. Politics and Governance, 9(3), 288-300.

Edwards, D. (1999). Emotion discourse. Culture \& Psychology, 5(3), 271-291.

Ford, R., \& Goodwin, M. (2014). Revolt on the right: Explaining support for the radical right in Britain. Routledge.

Gani, A. (2015, January 16). Who are Britain's 1mplus missing voters? The Guardian. https://www. theguardian.com/uk-news/2015/jan/16/britains$1 \mathrm{~m}$-missing-voters

Goodwin, M. (2015). UKIP, the 2015 general election and Britain's EU Referendum. Political Insight, 6(3), 12-15.

Hughes, C. (2019). It's the EU immigrants stupid! UKIP's core-issue and populist rhetoric on the road to Brexit. European Journal of Communication, 34(3), 248-266.

Jay, S., Batruch, A., Jetten, J., McGarty, C., \& Muldoon, O. T. (2019). Economic inequality and the rise of farright populism: A social psychological analysis. Journal of Community and Applied Social Psychology, 29, 418-428.

Kemmers, R., van der Waal, J., \& Aupers, S. (2016). Becoming politically discontented: Antiestablishment careers of Dutch nonvoters and PVV voters. Current Sociology, 64(5), 757-774.

Levitt, H. M., Bamberg, M., Creswell, J. W., Frost, D. M., Josselsohn, R., \& Suárez-Orozco, C. (2018). Journal article reporting standards for qualitative primary, qualitative meta-analytic, and mixed methods research in psychology: The APA publications and communications board task force report. American Psychologist, 73(1), 26-46.

McKenzie, L. (2017a). 'It's not ideal': Reconsidering 'anger' and 'apathy' in the Brexit vote among an invisible working class. Competition \& Change, 21(3), 199-210.

McKenzie, L. (2017b). The class politics of prejudice: Brexit and the land of no-hope and glory. The British Journal of Sociology, 68, S265-S280.

Mols, F., \& Jetten, J. (2016). Explaining the appeal of populist right-wing parties in times of economic prosperity. Political Psychology, 37, 275-292.

Mudde, C., \& Kaltwasser, C. R. (2017). Populism: A very short introduction. Oxford University Press.

Obradović, S., Power, S. A., \& Sheehy-Skeffington, J. (2020). Understanding the psychological appeal of populism. Current Opinion in Psychology, 35, 125-131.

Office for National Statistics. (2019). Electoral statistics for the UK [Data set]. Office for National Statistics. https://www.ons.gov.uk/peoplepopulationand community/elections/electoralregistration/datasets/ electoralstatisticsforuk 
Probyn, E. (2005). Blush: faces of shame. University of Minnesota Press.

Salmela, M., \& Capelos, T. (2021). Ressentiment: A complex emotion or an emotional mechanism of psychic defences? Politics and Governance, 9(3), 191-203.

Salmela, M., \& von Scheve, C. (2017). Emotional roots of right-wing political populism. Social Science Information, 56(4), 567-595.

Salmela, M., \& von Scheve, C. (2018). Emotional dynamics of right- and left-wing political populism. Humanity \& Society, 42(4), 434-454.

Smeekes, A. (2019). Longing for the good old days of 'our country': Understanding the triggers, functions and consequences of national nostalgia. In S. Mukherjee \& P. S. Salter (Eds.), History and collective memory from the margins: A global perspective (pp. 53-77). Nova Science Publishers.

Sullivan, G. B. (2018). Collective emotions: South African pride, euphoria and unity in the context of the 2010 FIFA World Cup. Frontiers in Psychology, 9, Article 1252. https://doi.org/10.3389/fpsyg.2018.01252

Sullivan, G. B., \& Day, C. (2019). Collective emotions in celebratory, competitive and conflictual contexts: Exploring the dynamic relations between groupbased and collective pride and shame. Emotions: History, Culture, Society, 3, 202-222.
Taylor, C., Nanz, P., \& Taylor, M. B. (2020). Reconstructing democracy: How citizens are building from the ground up. Harvard University Press.

Walkerdine, V. (2020). 'No-one listens to us': Post-truth, affect and Brexit. Qualitative Research in Psychology, 17(1), 143-158.

Wetherell, M. (2012). Affect and emotion: A new social science understanding. SAGE.

Wetherell, M., McConville, A., \& McCreanor, T. (2020). Defrosting the freezer and other acts of quiet resistance: Affective practice theory, everyday activism and affective dilemmas. Qualitative Research in Psychology, 17(1), 13-35.

Wohl, M. J. A., Stefaniak, A., \& Smeekes, A. (2020). Longing is in the memory of the beholder: Collective nostalgia content determines the method members will support to make their group great again. Journal of Experimental Social Psychology, 91, Article 104044.

Wyn Jones, R., Lodge, G., Jeffery, C., Gottfried, G., Scully, R., Henderson, A., \& Wincott, D. (2013). England and its two unions: The anatomy of a nation and its discontents. Institute for Public Policy Research. https://www.ippr.org/publications/england-andits-two-unions-the-anatomy-of-a-nation-and-itsdiscontents

\section{About the Author}

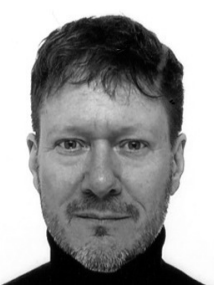

Gavin Sullivan is a Professor of Social Psychology for the International Psychoanalytic University Berlin and a Professor of Social and Political Psychology in the Centre for Trust, Peace and Social Relations, Coventry University. His research adopts an interdisciplinary social psychological research approach towards such topics as group-based and collective emotions (e.g., pride and shame), collective memory, crowd behaviour, disaster preparedness, and recovery (e.g., from eruptions, earthquakes, and multi-hazard events), political disengagement, populism and reactionary orientations, protests, and collective action. 